Ruth Ann Strickland. (1993) "The Twenty Seventh Amendment and Constitutional Change By Stealth." PS: Political Science and Politics 26 (December, no. 4): 716-722 (ISSN: 0030-8269) Published by Cambridge University Press for the American Political Science Association

\title{
The Twenty-Seventh Amendment and Constitutional Change by Stealth.
}

Ruth Ann Strickland.

\begin{abstract}
The 27th Amendment to the US Constitution, which states that any adjustment in compensation to legislators could take effect only after a new election was held, was ratified in 1992, some 203 years after it was first proposed. The amendment passed as a reaction of voters to a 1989 proposal by legislators for a increase in their salaries by $51 \%$, from $\$ 89,500$ to $\$ 135,000$ per annum. A question as to the constitutionality of an amendment that took more than two centuries to pass is being raised.
\end{abstract}

\section{ARTICLE}

The process of how to amend the U.S. Constitution is the least discussed and least examined aspect of the Constitution. The vagaries surrounding the amendment process were highlighted in 1992 as the Twenty-Seventh Amendment gained momentum and eventual ratification.

\section{Compensation of Members of Congress: The Twenty-Seventh Amendment}

As one of the original proposals accompanying the Bill of Rights, and first proposed in 1789, the congressional pay raise amendment was included in order to limit the ability of Congress to change the compensation of its members. It was proposed by James Madison and later passed by both houses of Congress. The amendment stated: "No law, varying the compensation for the services of senators and representatives, shall take effect until an election of representatives shall have intervened." Three state conventions, concerned that members of Congress might arbitrarily grant themselves salary raises, proposed that no salary improvements should occur before the next election of representatives (Livingston 1956). 
Six states approved the amendment within two years of its proposal by Congress. In 1873, one more state ratified it. Then, nothing happened again until 1978 when Wyoming ratified it. Once put into effect, the amendment would prevent Congress from giving itself a midterm pay raise; the raise would be delayed until after the subsequent House of Representatives election. The amendment also might void cost-of-living raises that Congress placed in previous pay raise bills; automatic raises passed in this manner could be considered unconstitutional ("Late Vote" 1992, 19; McAllister 1992c; Murray 1990; Moss 1992). The 24-word measure, now the TwentySeventh Amendment, was submitted TABULAR DATA OMITTED to 14 states for ratification in 1789, and after 203 years was only recently ratified in 1992.

Fifteen states of the necessary 38 required for ratification gave their support to the amendment since 1989, the year Congress gave itself a large pay raise. The amendment was neglected until the early 1980s until it was discovered by a state legislative aide in Texas, Gregory D. Watson, who lead a campaign that resulted in its revival (McAllister 1992b). By May 1992, 40 states had ratified the congressional pay raise amendment.

On May 14, 1992, Don Wilson, the archivist of the United States, certified the adoption of the amendment in accordance with Section 106b, Title I of the United States Code, thereby making it the Twenty-Seventh Amendment to the United States Constitution (Taylors World of Politics 1992; Kole 1992).

Why did this amendment gain so much momentum since 1978, the year states began to reconsider it in the twentieth century?

\section{The Amendment Process}

Article V of the U.S. Constitution represents not only a means of constitutional revisions but also an effort to contain revolution by delineating specific procedures for amending and possibly reconstituting government. The framers of the Constitution instituted a set of amendment procedures that allowed change in an orderly fashion, with no violent and abrupt disruption that would destroy public and private rights (Kyvig 1986).

Yet, the amendment process has been criticized by Wilson (1885), Bryce (1988), Ames (1896), Smith (1907), Livingston (1956), Dixon (1971), Burgess (1978), Schechter (1985), Dellinger (1986), and Berry (1986, 1987). They hold that existing constitutional amendment procedures require extraordinary concurrent majorities to initiate and ratify amendments and represent substantial hurdles to constitutional change by amendment. Many of these critics have proposed mechanisms for modifying the amendment process to ease its rigidity.

Klinglesmith (1925), Musmanno (1929, 1976), Pritchett (1959, 41), Mead (1987), Ginsburg (1989-1990), and Vile (1991, 1992a, 1992b) disagree with the critics and claim that the amendment process was constructed properly and serves its designed purpose. In their view, amending the Constitution should be difficult and should restrain the introduction of fad amendments--amendments that reflect spur of the moment consensus rather than enduring 
principles on which consensus has been reached. Others note the arduous nature of the amendment process, but claim that any effort to alter it would meet stiff political opposition and hold that such change is not likely to occur (Sundquist 1986).

Understanding why constitutional change by amendment has become more prevalent and more acceptable is a salient issue. The Twenty-Seventh Amendment explains how unexpected constitutional change can happen--how it may sneak up on us.

\section{Contrasting Views of Constitutional Change}

There are several theories of constitutional change by amendment.

Generational Rhythms: One broad conceptual method of analyzing political outputs in general is to characterize political change as responsive to generational rhythms. Changes in the "rhythm of political generations" has a profound effect on constitutional amendment policies. Each generation encounters a patterned set of political events and responds to them. Elazar (1978) delineated the intra-generational and inter-generational character of political change and asserted that a rhythm (within and between generations) exists in American politics.

Intra-generational change occurs at 25- and 40-year intervals and is defined by three stages. During the first stage of 10 to 15 years, actual issues and problems arise, new voters enter into the electoral process, and new solutions to problems are initiated. This stage is characterized by a few critical elections, which eventually result in a realignment of party identification (Schechter 1985, 178).

The second stage is an innovative period of three to four years in which new proposals are put forth to respond to the recognized problem. New political elites consolidate political control over a period of about 10 years. As stability is achieved, changes are initiated and institutionalized. The last stage lasts only a few years and closes the chapter of this generation as most of its proposals are ratified and opens a new chapter for an upcoming generation (Schechter 1985).

An inter-generational transition also occurs. It is not possible for the new generation to break totally with the old one. The same institutional arrangements and many similar issues carry over from one generation to the next. Some of the cultural norms and traditions of old generations are adopted and maintained by the new generation. In addition, the presence of some of the older generation political elites makes a complete break with the past impossible (Elazar 1978).

Using Elazar's typology, Schechter (1985) extrapolated five political generations: (1) the Founding generation (1789-1815); (2) the post-Civil War generation (1876-1948); (3) the Urban Frontier (1876-1919); (4) the New Deal generation (1920-1947); and (5) the post-World War II generation (1949-1978).

The clustering of amendments by generation is notable. The first 12 amendments were passed during the Founding generation. On average, most generations propose and adopt at least four 
amendments. The only generation not to propose an amendment was the Urban Frontier generation. The majority of amendment efforts, from introduction to Congress to the final ratification of the proposed amendment, averaged about 14.3 years. Of the original 26 amendments, five of them took over 30 years to take effect, from introduction in Congress to final ratification in the states. These included the abolition of slavery, the direct election of senators, prohibition, women's suffrage, the D.C. presidential vote, and the right of 18-year-olds to vote (Schechter 1985).

Shifting Political Coalitions: New political coalitions form and seek to maintain power by changing and rearranging rules of governance. The new dominant coalition is driven by grievances, promoting them to engage in a constitutional strategy that usually results in power loss for the new coalition's opponents (Grimes 1978). Scholars of this persuasion claim that amendment politics can be described by three major factors: (1) amendments tend to be passed in clusters; (2) amendment politics usually involves a regional or sectional aspect; and (3) amendment politics is characterized by a thrust towards equalitarian democracy (Grimes 1978, 25-26).

The use of several examples is illustrative. The Bill of Rights lessened the power of the Federalists and heightened the power of the Jeffersonians. The Civil War Amendments took power from the Southern Democrats and strengthened the Northeast. The Progressive Amendments weakened the eastern Republican Establishment by allowing the income tax and direct election of senators while the New Deal had the effect of cutting down the power of western Progressives by repealing prohibition. Finally the New Deal coalition was struck a blow by Republicans with the passage of the Twenty-Second Amendment, and the more recent civil liberties amendments have served to weaken the Old South's political structure (Grimes 1978, 166; Vose 1972).

TABLE 1

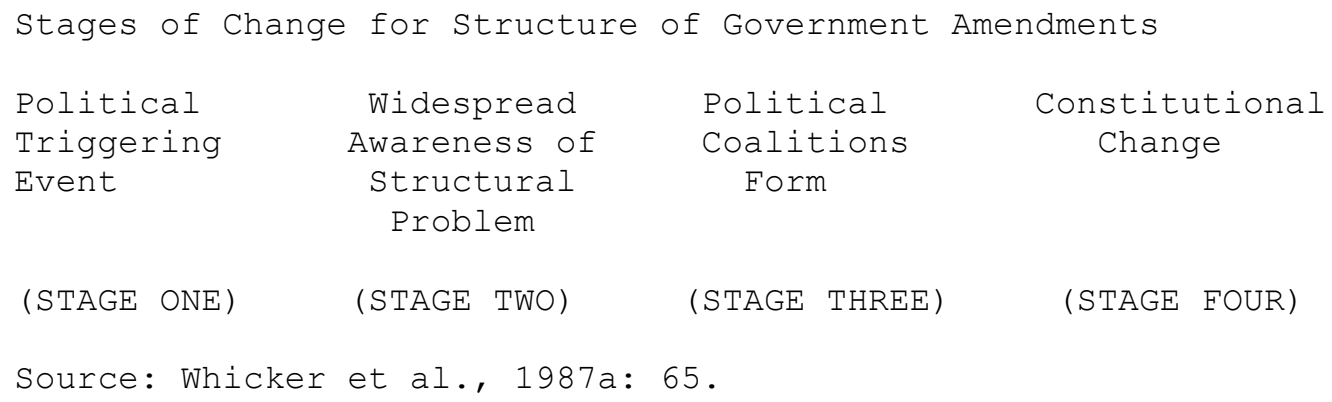

Political Triggering Events and Structural Amendments: Whicker, Strickland, and Moore (1987a, 1987b) attempt to explain the additional amendments to the Constitution by dividing the amendments into two categories: structure of government amendments and civil liberties amendments. These authors suggest that structure of government amendments are triggered by political crises or events whereas technological advances and economic changes are more likely to explain civil liberties amendment ratifications. Since the Twenty-Seventh Amendment is primarily a structural constitutional amendment, a focus on their model of structural constitutional change is required. 
In this model, politics, particularly elite-based politics, is more important in determining structure of government change than civil liberties revision. In the first stage, their model suggests that a political triggering event focuses attention upon a structural weakness in the government. Awareness of this deficiency builds motivation to rectify the weakness among relevant politicians and political elites in the second stage. As cognizance and motivation to remedy the deficiency increases, political coalitions form by stage three to demand a formal system response to the problem, which is highlighted by the political triggering event. In the final stage, a new constitutional amendment is ratified and the structural deficiency is eliminated.

\section{The Stealth Amendment: Congressional Pay Raise as Triggering Event}

A Confidence Crisis: The Twenty-Seventh Amendment was not ratified due to generational rhythms or shifting political coalitions. More likely, it was triggered by the growing disenchantment with congressional perquisites and arrogance. The probable passage of the Twenty-Seventh Amendment was further

reinforced by the "rubbergate" scandal on the Hill, as numerous members of the House of Representatives engaged in check kiting. When polled on this, very few Americans (22\%) were satisfied with explanations offered by various members of Congress, and few were very likely or somewhat likely $(20 \%)$ to reelect congressional representatives who were among the worst offenders (Hugick 1992).

Various public opinion polls indicate that substantial numbers of Americans have lacked confidence in government institutions, particularly Congress, which is supposed to be the most representative and responsive branch of government. In a Gallup poll conducted in September $1988,8 \%$ of the respondents had a great deal of confidence in Congress, $27 \%$ had quite a lot of confidence, $45 \%$ had some confidence, $16 \%$ had very little confidence, and $2 \%$ had no confidence in Congress as an institution. Compared to churches and organized religion, the military, the U.S. Supreme Court, banks, public schools, newspapers, television, organized labor and big business, Congress in 1988 ranked seventh highest among institutions in confidence levels. Congress ranked above only television, organized labor, and big business, receiving a rating of $35 \%$ by those who had a great deal or quite a lot of confidence TABULAR DATA OMITTED in the institution (Gallup Report 1988, 37).

TABLE 2

State Ratification Dates of the Twenty-Seventh Amendment
$\begin{array}{lll}\text { Year } & \text { Date } & \text { State } \\ 1789 & \text { December 19 } & \text { Maryland } \\ & \text { December 22 } & \text { North Carolina } \\ 1790 & \text { January 19 } & \text { South Carolina } \\ & \text { January 28 } & \text { Delaware } \\ 1791 & \text { November 3 } & \text { Vermont }\end{array}$


December 15

1873

1978

1983

1984

1985

1986

1987

1988

1989

1990

1991

1992
May 6

March 3

April 27

April 18

February 21

April 3

May 23

July 10

February 14

February 24

February 26

March 5

March 17

May 13

June 30

February 2

March 10

July 6

February 7

March 23

April 26

May 5

May 19

May 22

May 25

April 4

May 31

March 25

May 5

May 5

May 6

May 7

May 7
March 7
Virginia

Ohio

Wyoming

Maine

Colorado

South Dakota

New Hampshire

Arizona

Tennessee

oklahoma

New Mexico

Indiana

Utah

Arkansas

Montana

Connecticut

Wisconsin

Georgia

West Virginia

Louisiana

Iowa

Idaho

Nevada

Alaska

Oregon

Minnesota

Texas

Kansas

Florida

North Dakota

Alabama

Missouri

Illinois

Michigan

New Jersey

Source: Michaelis 1992a; Taylors World of Politics 1992.

In 1989, only $32 \%$ of Americans had a great deal or a lot of confidence in Congress as an institution; in 1990, this confidence dropped to 24\% (Gallup Report 1989, 20-21; Gallup and Newport 1991). By October 1991, Congress attained the lowest confidence ratings of any institution--a mere $18 \%$ had a great deal or a lot of confidence in Congress (Gallup and Newport 1991). 
In a Gallup Poll conducted in July 1992, the honesty and ethics of 25 professionals, including pharmacists, medical doctors, college teachers, engineers, police officers, journalists, bankers, and insurance salespersons, were compared. Those who were rated low or very low on honesty and ethical standards included lawyers (36\%), U.S. senators (40\%), U.S. representatives (43\%), and car salespersons (59\%). Elected officials in this poll experienced the sharpest decline in ratings in 16 years of polling. Congress, in particular, experienced the most rapid decline with only $13 \%$ of Americans believing that the U.S. Senate had high standards and only $11 \%$ believing this for members of the House. Only insurance salespersons, advertising practitioners, and car salespersons ranked lower than Congress (McAneny 1992).

Congressional Pay Raise Proposals as Triggering Event: In 1989, a nationwide poll revealed that $82 \%$ of Americans opposed the $51 \%$ pay raise proposal that would increase the salaries of members of Congress from $\$ 89,500$ to $\$ 135,000$ per year. Only $15 \%$ favored it (Gallup Report 1989). Although initially squelched, pay raises did eventually go into effect. Through 1989, members of both houses of Congress were paid $\$ 89,500$. But in 1990 , Senators earned $\$ 98,400$. By 1991, House of Representatives members' salaries were raised to $\$ 125,100$ and pay for senators rose to $\$ 101,900$. The 1989 Ethics Reform Act provided for cost-of-living raises to make up for inflationary losses from years when COLAs were not added to their salaries (Burger 1991, 1992). With the year of the angry voter and an anti-incumbent sentiment being heralded both in 1990 and 1992, it is no surprise that the public was searching for ways to rein in perceived arrogance (Hook 1990).

Groups such as Citizens Against Government Waste argued that pay increases ought to be linked to performance--implying that congressional performance on some issues, e.g., the economy, had not been good. Other groups, such as Ralph Nader's Congressional Accountability Project, Coalitions for America, National Taxpayers Union and Citizens for a Sound Economy, were also activated to roll back pay raises. The pressure exerted by groups in addition to angry voters led Congress to implement the $51 \%$ raise more gradually. Many voters could not understand the need for pay hikes, given that a salary of $\$ 89,500$ put congressional members among the top $1 \%$ of the nation's wage earners (Clift 1989; Deutsch 1991; Malin 1990; Shapiro 1989).

Since structural changes affect mostly politicians and elites, structural constitutional change is more likely to be elite-based whereas civil liberties constitutional change is more likely to be popularly based. The Twenty-Seventh Amendment captured the attention of organized groups as well as political elites. The precipitating or triggering events that drew the attention of political elites were the low estimation of Congress by the public as well as the public's outrage over recent congressional pay raises, in addition to other allegations of corruption involving various congressional members. Congress, weakened by the savings and loan debacle, House check kiting, and savings and loan banking scandals, as well as the mismanagement of the House Post Office, became a target of frustrated voters and reformers.

A Policy Entrepreneur: The Twenty-Seventh Amendment first caught the eye of Gregory D. Watson, a student at the University of Texas at Austin. In 1982, Watson was researching whether Congress could extend the ratification deadline for the Equal Rights Amendment and, in the course of this research, ran across Madison's stymied proposal. Watson worked night and day to revive the pay raise amendment and pushed for its passage in state legislatures. Watson had used 
$\$ 6,000$ of his own money, as of 1992 , to sponsor a nationwide effort to ratify the Madison amendment (McAllister 1992a; Murray 1990; Moss 1992; Parker 1989). Although he got a "C" on his research paper, Watson is credited with influencing 26 state legislatures to ratify the congressional pay raise amendment.

Political Coalitions Form: Awareness of the structural problem--Congress voting itself a pay raise at any time, and other scandals--grew. State legislatures began to ratify the Twenty-Seventh Amendment in rapid succession. Fifteen states, or almost $40 \%$ of those votes needed for ratification of the Twenty-Seventh Amendment, gave their support between February 7, 1989, and May 7, 1992.

Congress was under pressure to accept the amendment. In order to restore the legitimacy of the institution, many members of Congress, particularly newly elected members, felt compelled to support the amendment. In 1990, there were at least 14 congressional freshmen who supported the congressional pay raise amendment. By 1992, there were at least 35 Republicans and Democrats in the freshman class of Congress who supported the amendment (Wilkinson 1991; Garrett 1992a). Representative Charles Lukens stated that the push for support of the amendment was due to a feeling that "the American people are losing faith in Congress as an institution" (Wilkinson 1991). Political coalitions, especially among freshman members of Congress, formed to back the amendment, eventually gaining reluctant support from old-timers and sometimes challengers of the amendment such as Tom Foley, Speaker of the House, and George Mitchell, Majority Leader of the Senate.

\section{Legitimacy of the Twenty-Seventh Amendment}

Numerous scholars and politicians have been concerned about the legitimacy of the TwentySeventh Amendment, and have questioned its contemporaneousness or its timeliness (Vile 1992a; Garrett 1992b; Michaelis 1992a). Dick Howard, a constitutional law professor at the University of Virginia, was quoted as stating that he couldn't imagine the framers of the Constitution being unconcerned about how long it takes to ratify an amendment, indicating that in his view the Twenty-Seventh Amendment fails the contemporaneousness test. Norman Ornstein, a congressional scholar at the American Enterprise Institute, stated that the amendment did not meet the standard of timeliness. Walter Dellinger, a constitutional law professor at Duke University, characterized the Twenty-Seventh Amendment as a "casual" amendment. Dellinger also pointed out that James Madison, the author of the congressional pay raise amendment, was not overly supportive of the proposal at the time. As the amendment was debated in the First Congress, concerns were expressed that the unpopularity of low salaries might prevent good men from pursuing political offices (Horwitz 1992; Michaelis 1992c).

The U.S. Supreme Court, in its review of amending process issues, has been ambiguous in its decisions on the question of whether the Twenty-Seventh Amendment actually met the formal requirements of Article V. In Dillon v. Gloss (1921), the Supreme Court upheld the seven-year limit on ratification of the Eighteenth Amendment, as specified by Congress. The reasoning behind this conclusion was based on the idea that Article V "implied" that ratification of an 
amendment should occur within some "reasonable" time period which Congress is free to establish. The Court specifically stated:

... as ratification is but the expression of the approbation of the people and is to be effective when had in three-fourths of the States, there is fair implication that it must be sufficiently contemporaneous in that number of States to reflect the will of the people in all sections at relatively the same period, which of course ratification scattered through a long series of years would not do (Dillon v. Gloss, 253 U.S. 368, 375).

The Supreme Court also held that they found nothing in Article V to support the notion that once an amendment is proposed that it could be open for ratification indefinitely. The assumption in Dillon was that if states were allowed to consider amendments over a longer time frame than seven years, it would be possible to pass an amendment years down the road that no longer had the support of a substantial proportion of the population (Mead 1987). The Twenty-Seventh Amendment, however, had no ratification time limit deadline to meet.

In Coleman v. Miller (1939), the Supreme Court deferred to Congress, giving it the authority to set a reasonable time for ratification and to determine whether the lapse of time made an amendment proposal obsolete prior to receiving the required number of ratification votes from the states. Backing away somewhat from its more firm stance in Dillon, the Supreme Court in Coleman declared the issue of whether amendments were timely or not a political question--a question to be left up to congressional discretion (Caplan 1988, 110-14; Edel 1981; Vile 1992a).

It has been argued that by deferring to Congress in the Coleman decision, the Supreme Court left important constitutional questions about Article $\mathrm{V}$ unanswered. As a result, some major constitutional issues may be resolved on the basis of partisan whims, not stable constitutional rule of law. Vile (1992a) argued that the Twenty-Seventh Amendment should not have been accepted by Congress, nor should it set precedent for future court actions. Because the amending process surrounding the Twenty-Seventh was "scattered through a long series of years" and had been dormant for long periods of time, it should be regarded as a "stealth" amendment. It presents the specter of the revival of other amendments, which received only a few early state ratifications. It also appears to be a circumvention of the process--a short-cut around contemporary sentiment and an infusion of uncertainty about the fundamental basis of our law.

Although Representative Tom Foley (D-WA) and Senator Robert Byrd (D-WV) eventually accepted the need for the congressional pay raise amendment, they also voiced concerns about the time lapse between state ratification votes. Byrd, in particular, was upset with archivist Don Wilson for failing to postpone certification of the amendment until Congress could probe the questions about the validity of the ratification and engage in congressional discussion and debate about the necessity of the amendment (Michaelis 1992c; McAllister 1992b).

Others have argued that the Twenty-Seventh Amendment is legitimate. Thomas Durbin, a legislative attorney for the Congressional Research Service, claimed that states ratified the amendment in good faith, believing that they had the authority to do so and that their votes would count. Representative Hamilton Fish (R-NY) also argued that the recent rash of 
ratifications since 1982 indicated the contemporaneousness of the amendment proposal (DeBenedictis 1992; Michaelis 1992a; Michaelis 1992c).

\section{Conclusions}

With congressional acquiescence and with certification by the archivist, it appears that the Twenty-Seventh Amendment is here to stay and that its legitimacy has been established. When structural crises or problems emerge and political elites are activated, the Constitution can be amended by stealth and with great rapidity. The generational rhythm thesis does not help explain why the Twenty-Seventh Amendment was adopted because the amendment's ratification period extends over a 203-year time period, crossing numerous generations. The shifting political coalitions explanation offered by Grimes (1978) also does not apply in this case because there is no regional or ideological pattern associated with the passage of the amendment; regional or sectional adoption of the amendment in state legislatures was random, and the amendment garnered bipartisan political support. Constitutional change by amendment in this case was caused by political triggering events, which prodded key politicians at the state and national levels to recognize a structural deficiency and to pursue a constitutional remedy.

\section{References}

Ames, Herman V. 1896. The Proposed Amendments to the Constitution of the United States During the First Century of Its History. H. Doc. 353, pt. 2, 54th Cong., 2nd sess.

"Archivist to OK Pay Raise Amendment." 1992. Los Angeles Times (14 May): A17.

Berry, Mary Frances. 1986. Why the ERA Failed: Politics, Women's Rights, and the Amending Process of the Constitution. Bloomington, IN: Indiana University Press.

Berry, Mary F. 1987. "How Hard It Is to Change." New York Times Magazine (13 September): 93-98.

Bryce, James. 1888. The American Commonwealth, Vol. 1. London and New York: MacMillan and Co.

Burger, Timothy J. 1991. "House Members' Annual Salaries Are Hiked to \$125,000 This Week; Senators' to \$101,900." Roll Call (3 January).

Burger, Timothy J. 1992. "Members to Get Automatic COLA Raise of 3.5\%; Staff Caps

Expected to Rise, Too." Roll Call (6 January).

Burgess, John W. 1978. Selections from Political Science and Comparative Constitutional Law. Farmingdale, NY: Dabor Social Science Publications. 
Caplan, Russell L. 1988. Constitutional Brinkmanship: Amending the Constitution by National Convention. New York: Oxford University Press.

Clift, Eleanor. 1989. "The Tea-Bag Revolution: A Backlash Over the Congressional Pay Raise." Newsweek 113 (6 February, no. 6): 18.

Coleman v. Miller. 1939. 307 U.S. 433.

Coyle, Marcia. 1992. "No Set Procedure for Amendments." National Law Journal 14 (1 June, no. 39): 10.

DeBenedictis, Don J. 1992. "27th Amendment Ratified; Congressional Vote Ends Debate Over 203-Year-Old Pay-Raise Proposal." American Bar Association Journal 78 (August): 26.

Dellinger, Waiter. 1986. "The Process of Constitutional Amendment: Law, History, and Politics." News for Teachers of Political Science 49 (Spring): 16-19.

Deutsch, Jack. 1991. "Nader Says Pay Raise Still Can Die." Charleston (West Virginia) Daily Mail (1 January).

Dillon v. Gloss. 1921. 256 U.S. 368.

Dixon, Robert G., Jr. 1971. "Article V: The Comatose Article of Our Living Constitution?" In The Article V Convention Process. New York: Da Capo Press.

Edel, Wilbur. 1981. A Constitutional Convention: Threat or Challenge? New York: Praeger Publishers.

Elazar, Daniel. 1978. "The Generational Rhythm of American Politics." American Politics Quarterly 6 (January): 55-94.

Elazar, Daniel J. 1985. "Constitution-making: The Pre-eminently Political Act." In Redesigning the State: The Politics of Constitutional Change, ed. Keith G. Banting and Richard Simeon.

Toronto: University of Toronto Press.

Gallup, George, and Frank Newport. 1991. "Confidence in Major U.S. Institutions at All-Time Low." Gallup Poll Monthly (October, no. 313): 36-40.

Gallup Report. 1988. "Confidence in Institutions." (December, no. 279): 30, 37.

Gallup Report. 1989. "8 in 10 Americans Oppose Congressional Pay Raise." (February, no. 281): 6-7.

Gallup Report. 1989. "Confidence in Institutions." (September, no. 288): 20-21.

Garrett, Major. 1992a. "Democrats Stall on Raise Amendment." Washington Times (14 May). 
Garrett, Major. 1992b. "Foley Endorses Pay Raise Curbs." Washington Times (15 May).

Ginsburg, Ruth B. 1989-1990. "On Amending the Constitution: A Plea for Patience." University of Arkansas at Little Rock Journal 12: 677-94.

Grimes, Alan P. 1978. Democracy and the Amendments to the Constitution. Lexington, MA: D.C. Heath.

Hook, Janet. 1990. "Incumbents Get the Jitters as Voters Grow Angry." Congressional Quarterly Weekly Report 48 (4 August, no. 31): 2473-77.

Horwitz, Paul. 1992. "Boehner Cites Analysis Claiming 27th Amendment Is Already Law." Roll Call (11 May).

Hugick, Larry. 1992. "The Rubbergate Scandal." Gallup Poll Monthly (March, no. 318): 2-4.

Klinglesmith, Margaret C. 1926. "Amending the Constitution of the United States." University of Pennsylvania Law Review 10 (February): 185-206.

Kyvig, David E. 1986. "Alternative to Revolution: Two Hundred Years of Constitutional Amending." In The Embattled Constitution: Vital Framework or Convenient Symbol, ed. Adolph H. Grundman. Malabar, FL: Robert E. Krieger Publishing Co.

"Late Vote." 1992. Time 139 (25 May): 19.

Livingston, William S. 1956. Federalism and Constitutional Change. Oxford: Clarendon Press.

Malin, Jay. 1990. "Coalition Plans Campaign to Fight Congress' Pay Raises." Washington Times (3 August).

McAllister, Bill. 1992a. "Madison's Brainchild Comes to Life." Washington Post (8 May).

McAllister, Bill. 1992b. "It's Never Too Late: In the End James Madison Has His Way." Washington Post National Weekly (18-24 May): 34.

McAllister, Bill. 1992c. "Now That the 27th Amendment Is Law, What Does It Mean?" Washington Post National Weekly (25-31 May): 34.

McAneny, Leslie. 1992. "Pharmacists Again Top Honesty and Ethics Poll; Ratings for Congress Hit New Low." Gallup Poll Monthly (July, no. 322): 2-4.

Mead, Walter B. 1987. The United States Constitution: Personalities, Principles, and Issues. Columbia, SC: University of South Carolina Press.

Michaelis, Laura. 1992a. "1789 Pay Raise Amendment Returns to Haunt Congress." Congressional Quarterly Weekly Report 50 (9 May, no. 19): 1230-31. 
Michaelis, Laura. 1992b. "Both Chambers Rush to Accept 27th Amendment on Salaries." Congressional Quarterly Weekly Report 50 (16 May, no. 20): 1323.

Michaelis, Laura. 1992c. "James Madison Gets His Way as Congress Ducks Issue." Congressional Quarterly Weekly Report 50 (23 May, no. 21): 1423.

Moss, J. Jennings. 1992. "House, Senate OK Amendment." Washington Times (21 May).

Murray, Frank J. 1990. "Giving Voice to Madison's Words." Washington Times (16 July).

Musmanno, M. A. 1929. "The Difficulty of Amending Our Federal Constitution: Defect or Asset?" American Bar Association Journal 15: 505-08.

Musmanno, M. A. 1976. Proposed Amendments to the Constitution: A Monograph on the Resolutions Introduced in Congress Proposing Amendments to the Constitution of the United States of America. Westport, CT: Greenwood Press.

Parker, Alan A. 1989. "What Goes Around Comes Around." Trial 25 (April, no. 5): 10-11.

Pritchett, C. Herman. 1959. The American Constitution. New York: McGraw Hill.

Schechter, Stephen L. 1985. "Amending the United States Constitution: A New Generation on Trial." In Redesigning the State: The Politics of Constitutional Change, ed. Keith G. Banting and Richard Simeon. Toronto: University of Toronto Press.

Shapiro, Joseph P. 1989. "Should Congress Get a 51 Percent Raise?" |interviews U.S. News \& World Report 106 (13 February, no. 6): 28.

Smith, James Allen. 1907. The Spirit of American Government. New York: MacMillan Co.

Strickland, Ruth Ann. 1989. "The Ratification of U.S. Constitutional Amendments: Each State Having One Vote as a Form of Malapportionment." Ph.D. diss., University of South Carolina.

Strickland, Ruth Ann. 1992. "Population Size, Diversity and the Proclivity of States to Oppose or Support the Ratification of Amendments to the U.S. Constitution." Southeastern Political Review 20 (Fall, no. 2): 269-93.

Sundquist, James L. 1986. Constitutional Reform and Effective Government. Washington, DC: Brookings Institution.

Taylors World of Politics. 1992. "The 27th Amendment." Vol. 13 (July): 5.

Vile, John R. 1991. "Rewriting the United States Constitution: An Examination of Proposals from Reconstruction to the Present." New York: Praeger. 
Vile, John R. 1992a. "Just Say No to 'Stealth' Amendment." National Law Journal 14 (22 June, No. 42): 15 .

Vile, John R. 1992b. The Constitutional Amending Process in American Political Thought. New York: Praeger.

Vose, Clement E. 1972. Constitutional Change: Amendment Politics and Supreme Court Litigation Since 1900. Lexington, MA: D.C. Heath.

Whicker, Marcia Lynn, Ruth Ann Strickland, and Raymond A. Moore. 1987a. "The Constitution Under Pressure: The Amendment Process." Journal of Political Science 15 (Spring, nos. 1 and 2): 60-71.

Whicker, Marcia Lynn, Ruth Ann Strickland, and Raymond A. Moore. 1987b. The Constitution Under Pressure: A Time for Change? New York: Praeger Publishers.

Wilkinson, Howard. 1991. "Congressional Limits: Lawmakers Revive 1789 Plan to Curb Salary Powers." Cincinnati Enquirer (2 August).

Wilson, Woodrow. 1885. Congressional Government: A Study in American Politics. Boston: Houghton Mifflin and Co.

Note: Newspaper articles cited here without page numbers were obtained from the Newsbank Electronic Information System, Newsbank Reference Service. 